\title{
Chemical composition of snow crab shells (Chionoecetes opilio) Composición química del caparazón del cangrejo de las nieves (Chionoecetes opilio)
}

\author{
María -Asunción Lage-Yusty , María Vilasoa-Martínez , Susana Álvarez-Pérez \\ \& Julia López-Hernández
}

To cite this article: María -Asunción Lage-Yusty , María Vilasoa-Martínez, Susana Álvarez-Pérez \& Julia López-Hernández (2011) Chemical composition of snow crab shells (Chionoecetes opilio) Composición química del caparazón del cangrejo de las nieves (Chionoecetes opilio), CyTA Journal of Food, 9:4, 265-270, DOI: 10.1080/19476337.2011.596285

To link to this article: https://doi.org/10.1080/19476337.2011.596285

(2) Copyright Taylor and Francis Group, LLC

Published online: 04 Nov 2011.

Џ Article views: 5102
+ View supplementary material $₫$

13 Submit your article to this journal ๘

Citing articles: 7 View citing articles $[\pi$ 


\title{
Chemical composition of snow crab shells (Chionoecetes opilio)
}

\section{Composición química del caparazón del cangrejo de las nieves (Chionoecetes opilio)}

\author{
María-Asunción Lage-Yusty*, María Vilasoa-Martínez, Susana Álvarez-Pérez and Julia López-Hernández \\ Department of Analytical Chemistry, Nutrition and Bromatology, Faculty of Pharmacy, University of Santiago de Compostela, \\ 15782 Santiago de Compostela, Spain
}

(Received 29 March 2011; final version received 8 June 2011)

\begin{abstract}
The snow crab (Chionoecetes opilio) shells have potential important economical and industrial applications due to their chemical composition. They have a high content of protein $(34.2 \% \mathrm{dw})$ and essential amino acids; they also have fat $(17.1 \% \mathrm{dw})$, with a high proportion of $\omega 3$ polyunsaturated fatty acids. About $28.5 \% \mathrm{dw}$ corresponds to ash (calcium, phosphorous, and magnesium are the major minerals). The mean concentrations of vitamin E, astaxantin, and $\beta$-carotene were $23.3,9.49$, and $0.2 \mathrm{mg} / 100 \mathrm{~g} \mathrm{dw}$, respectively. Results presented in this study indicate that snow crab by-products may serve as excellent nutritional components for future applications in the health and food sectors.
\end{abstract}

Keywords: shells of Chionoecetes opilio; composition; proteins; lipids; vitamin E; ash and minerals; high added value compounds

\begin{abstract}
Los caparazones del cangrejo de las nieves (Chionoecetes opilio) pueden tener aplicaciones industriales y económicas potencialmente importantes debido a su composición química. En su composición destaca el elevado contenido en proteínas $(34,2 \% \mathrm{~ms})$ y aminoácidos esenciales, en lípidos totales $(17,1 \% \mathrm{~ms})$, con una elevada proporción de ácidos grasos poliinsaturados $\omega 3$, en cenizas $(28 \%(\mathrm{~ms})$, principalmente calcio, fosfatos y magnesio. La concentración media de vitamina E es de $23,3 \mathrm{mg} / 100 \mathrm{~g} \mathrm{~ms}$, de astaxantina $9,49 \mathrm{mg} / 100 \mathrm{~g} \mathrm{~ms}$, de $\beta$-caroteno $0,2 \mathrm{mg} / 100 \mathrm{~g} \mathrm{~ms}$. El alto contenido en nutrientes, puesto de manifiesto en este estudio, indica que los productos de desecho del cangrejo de las nieves pueden ser utilizados como productos de alto valor añadido para su aplicación en suplementación de dietas para alimentación humana y acuicultura.
\end{abstract}

Palabras clave: caparazón de Chionoecetes opilio; composición; proteínas; lípidos; vitamina E; cenizas y minerales; compuestos de alto valor añadido.

\section{Introduction}

In recent years, the exhaustion of marine resources is a reality all over the world even in the case of resources regulated internationally by FAO through the Regional Fishery Bodies (http://www.fao.org/fishery/en). Annual discard of the fisheries worldwide are estimated to be ca. 20 million tons, which represents $25 \%$ of the catch and include "non-targeted" species, processing waste, and by-products (Ferraro et al., 2010). Waste and by-products discharged by the fisheries are currently increasing and it poses a serious environmental problem.

The seafood consumption has consistently increased during the recent years, as seafood has been progressively recognized as an important source of nutrients for human health. A very high percentage of captures are not considered useful because they are not profitable due to their low consumer acceptability. Nevertheless, these captures apart from reducing waste of marine resources, may have intrinsic nutritious value as source of high added value compounds, suitable for human health applications (Ferraro et al., 2010).

As the global supplies of fish meal and fish oil limit further expansion in the fast growing seafood industry, initiatives to study alternative sources of raw materials for food and feed production will reduce the pressure on the limited marine resources and enable development of more cost-effective feeds.

Marine invertebrates are widely being used as food and feed supplement around the world and may be used in enrichment of diet and new value-added products to decrease processing waste and increase profits (Obatolu, Skonberg, Camire, \& Dougherty, 2005; Tibbetts, Olsen, \& Lall, 2011; Velu \& Munuswamy, 2007). These by-products have applications in the food industry, including health-promoting ingredients such as marine oils and calcium, as well as enzymes, antioxidants, flavorings, and pigments (Shahidi, 2006). Crabs, among many other invertebrates, are considered to be an important shell fishery product. The demand for products derived from fishing has 
increased considerably. This has prompted a sustained upward development in aquaculture activity, and a corresponding increase in the need for fish feed. Success in aquaculture is based on various criteria, in which selection of a suitable feed and its potential use is important. Crustacean-processing waste or by-product has traditionally been added to animal feeds. These by-products contain pigments, flavor components, calcium, and other minerals, as well as high-quality protein and can also be used to create value-added products (Heu, Kim, \& Shahidi, 2003; Mach, Nguyen, \& Nortvedt, 2010; Murphy et al., 2003; Oliveira Cavalheiro, Oliveira de Souza, \& Bora 2007; Rosa \& Nunes, 2003; Shahidi \& Synowiecki, 1991; Skonberg, Donahue, Bayer, Floreto, \& Riley, 2001; Tibbetts et al., 2011; Toppe, Aksnes, Hope, \& Albrektsen, 2006; Velu \& Munuswamy, 2007). Marine by-products represent a source of lipids of interest to the health, nutrition, aquaculture, and cosmetology industry (Beaulieu, Thibodeau, Bryl, \& Carbonneau, 2009).

Snow crabs, Chionoecetes opilio (Brachyura: Majidae), are found throughout the Northeast Atlantic (from Greenland to the Gulf of Maine), the northern Pacific, the Bering Sea, the Arctic Ocean, and the Sea of Japan (http://www.glf.dfo-mpo.gc.ca). The snow crab diet is diverse and is composed primarily of algae, crustaceans (shrimp, crab, amphipods, copepods, isopods, and ostracods), mollusks, and worms. Commercial fishery of this crustacean started in 1966 after exploratory surveys discovered the first major stocks of snow crab in the Gulf of St. Lawrence (http:// www.fao.org/fishery/species/2644/en). Since then, new stocks have been located almost every year. The main fishing grounds are found from southeast of the Gaspe Peninsula (Quebec) to the Magdalen Islands of the Gulf, around Cape Breton Island and in southwestern Nova Scotia. There are also some fishing grounds around Newfoundland (http://www.dfo-mpo.gc.ca/ $\mathrm{fm}$-gp/peches-fisheries/ifmp-gmp/snow-crab-neige/snowcrab-neiges2009-eng.htm).

The countries with the largest catches reported for this species by FAO for 1999 were Canada (95.115 t) and St. Pierre and Miquelon (589 t). The landed volume of snow crab for Canada in 2004 was $103.00 \mathrm{t}$ and in 2006, $90.000 \mathrm{t}$ (http://www.fao.org/fishery/ species/2644/en). The quantity of snow crab landed and exported from Canada to the rest of the world has remained stable in recent years (between 90.000 and $100.000 \mathrm{tm}$ landed and around $50.000 \mathrm{tm}$ exported), and the principal markets are in US and Japan (http:// www.dfo-mpo.gc.ca/index-eng.htm). Although snow crab is caught in considerable amounts, the only part that is marketed, usually in Japan, is the legs (claws), while the rest of their anatomy (that is to say, the cephalotorax) is wasted completely. Average size crab in the commercial catch has shell size approximately $11 \mathrm{~cm}$ in width and $0.5 \mathrm{~kg}$ dry weight. Female shells rarely reach the size of $9.5 \mathrm{~cm}$ and a fully grown male crab is approximately twice as large, reaching a maximum shell width of $14 \mathrm{~cm}$. Male snow crabs become commercially viable when their shell width reaches $9.5 \mathrm{~cm}$.

Snow crab exploitation generates important volumes of by-products because of their abundance and relative ease of capture. These shell wastes constitute valuable sources of components and a potential new industrial resource (Beaulieu et al., 2009; Ferraro et al., 2010) because it is a nutritional and valuable source of protein (Mach et al., 2010; Vilasoa-Martínez, Lopez-Hernandez, \& Lage-Yusty, 2007), lipids (Vilasoa-Martínez, Rodríguez Bernaldo de Quirós, López Hernández, \& Lage Yusty, 2009), and carotenoids (Christiansen \& Torrissen, 1996; Vilasoa-Martínez et al., 2008).

As a whole, seafood products have been claimed for their health-promoting characteristics. The aim of the present study was to know the chemical composition of discarded snow crab shells in terms of proteins, amino acids, total fat and profile of fatty acids, ash (phosphorus, calcium, and magnesium), vitamin E, and carotenoids in order to explore possibilities for future applications in the health and food sectors.

\section{Materials and methods}

\section{Samples (harvest and preparation)}

The male snow crabs (Chionoecetes opilio) were harvested from the North Atlantic between Greenland and Canada; 30 samples in October $2003\left(65^{\circ} 40^{\prime} \mathrm{N}\right.$, $\left.54^{\circ} 30^{\prime} \mathrm{W}\right)$ and 40 samples in November $2005\left(63^{\circ} 45^{\prime} \mathrm{N}\right.$, $53^{\circ} 04^{\prime} \mathrm{W}$ ) were collected. Meat from body and claw portions of the crab were separated by hand and dedicated for sale as a food product. For the purposes of this study, shells were frozen in the ship and transferred to our laboratory where they were defrosted using steam until most of the surface water was eliminated. Afterward, shells were weighed to determine percentage of moisture; dried at $50^{\circ} \mathrm{C}$ for $48 \mathrm{~h}$ and in a vacuum oven for $4 \mathrm{~h}$ until a constant weight was attained. After cooling to room temperature, samples were weighed again, homogenized (Omnimixer homogenizer 17106), and stored in the freezer until the analysis.

Samples were subjected to proximate composition analysis by the following determinations: Kjeldhal nitrogen, amino acids, total fat and profile, ash (phosphorus, calcium, and magnesium), vitamin E, and carotenoids. Samples have been analyzed by duplicate.

\section{Proximate composition analysis}

Proteins and amino acids were determined in the samples according to Vilasoa-Martinez et al. (2007). Proteins were determined by Kjeldhal nitrogen method 
using a bloc-digest, at optimal time and temperature conditions $\left(125^{\circ} \mathrm{C}\right.$ for $30 \mathrm{~min}, 200^{\circ} \mathrm{C}$ for $30 \mathrm{~min}$, and $400^{\circ} \mathrm{C}$ for $120 \mathrm{~min}$ ), followed by a distillation of the obtained nitrogen in a distilling unit (J.P. Selecta, S.A., Spain). Crude protein content was calculated from the nitrogen content by multiplying by 6.25 .

An HPLC method was used to analyze the amino acids [L-alanine (Ala), L-arginine (Arg), L-aspartic acid (Asp), L-glutamic acid (Glu), L-glycine (Gly), L-histidine (His), L-isoleucine (Ileu), L-leucine (Leu), L-lysine (Lys), L-methionine (Met), L-phenylalanine (Phe), L-proline (Pro), L-serine (Ser), L-threonine (Thr), L-tyrosine (Tyr), and L-valine (Val) were obtained from Sigma Chemical Madrid, Spain] in dried crab shells after derivatization with phenylisothiocyanate. The resulting amino acids were chromatographed on an ODS2 column with UV detection at $254 \mathrm{~nm}$. The mobile phase was a mixture of $0.14 \mathrm{M}$ sodium acetate buffer, $\mathrm{pH}$ 6.2, containing $0.05 \%$ triethylamine and 60:40 (v/v) acetonitrile-water, at a flow rate of $0.9 \mathrm{~mL} / \mathrm{min}$.

Total lipids and fatty acid profile (C14:0; C16:0; $\mathrm{C} 16: 1 \omega 7 ; \quad \mathrm{C} 16: 2 \omega 4 ; \quad \mathrm{C} 18: 0 ; \quad \mathrm{C} 18: 1 \omega 9 ; \quad \mathrm{C} 18: 1 \omega 7$; $\mathrm{C} 18: 2 \omega 6 ; \quad \mathrm{C} 18: 3 \omega 4 ; \quad \mathrm{C} 18: 3 \omega 3 ; \quad \mathrm{C} 18: 4 \omega 3 ; \quad \mathrm{C} 20: 0$; $\mathrm{C} 20: 1 \omega 9 ; \quad \mathrm{C} 20: 2 \omega 6 ; \quad \mathrm{C} 20: 4 \omega 6 ; \quad \mathrm{C} 20: 3 \omega 3 ; \quad \mathrm{C} 20: 4 \omega 3$;

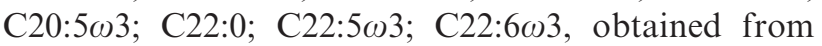
Supelco, Bellefonte PA, USA, as fatty acid-methyl ester) were determined according to Vilasoa-Martinez et al. (2009). Total lipids were determined using the Soxhlet system and petroleumbenzine as solvent. The fatty acid profile was determined by gas chromatography-flame ionization detection using a one-stepextraction-methylation method to obtain acid methyl esters.

Ash content was determined by dry ashing in a furnace oven at $\leq 550^{\circ} \mathrm{C}$ until the grey ash was obtained (AOAC, 1990). The ash was then used for mineral determination. Phosphate standard solutions of $1 \mathrm{~g} \mathrm{P} / \mathrm{L}$ were prepared in water with potassium dihydrogen phosphate. Aliquot portions were quantitatively transferred and diluted to obtain the working solutions. Standard curves between 2 and $60 \mathrm{mg} / \mathrm{L}$ were used for the determination of phosphorus, using molibdate-vanadate reagent and measuring absorbance at $430 \mathrm{~nm}$ in a spectrophotometer Cary 3E UV-Visible (Varian, Australia).

For the determination, the molibdate-vanadate reagent (known volume) was added to ash aliquot $(10 \mathrm{mg})$, and the results were expressed in absorbance at $430 \mathrm{~nm}$. Standard curves were used for the determination of phosphorus.

Regarding calcium and magnesium, an ash aliquot (20 mg) was digested in nitric acid. Both minerals were determined by complexometry, using $\mathrm{NaOH} 35 \%$ as buffer and calcon carboxilic acid as indicator for calcium and buffer $\mathrm{NH}_{3} / \mathrm{ClNH}_{4}$ and Eriochrome black $\mathrm{T}$ as indicator for magnesium, and Titriplex as reagent of titration.
Vitamin E and carotenoids were determined according to Vilasoa-Martinez et al. (2008). Vitamin $\mathrm{E}$ and carotenoids were extracted with acetone (1 $\mathrm{g}$ of dry sample was extracted using three portions of $5 \mathrm{~mL}$ of acetone) and evaporated until dryness in a rotavapor system. The residue was dissolved in methanol-hexane-dichloromethane and injected into HPLC coupled with UV-Vis and fluorescence detectors. The carotenoids were determined with diodearray detector $(\lambda \quad 450 \mathrm{~nm}$ ), and vitamin $\mathrm{E}$ with fluorescence detector ( $\lambda$ ex $288 \mathrm{~nm}$, $\lambda$ em $331 \mathrm{~nm}$ ) in gradient using a mobile phase consisting of methanol as solvent $\mathrm{A}$, acetonitrile as solvent $\mathrm{B}$, and hexanedichloromethane as solvent $\mathrm{C}$.

\section{Results}

The mean width and length of shells were $11.3 \pm 0.95 \mathrm{~cm}$ by $11.8 \pm 0.93 \mathrm{~cm}$ and the mean weight was $116.4 \pm 30 \mathrm{~g}$ for samples harvested in 2003, and the mean width and length of shells were $12.4 \pm 1.0 \mathrm{~cm}$ by $11.1 \pm 1.0 \mathrm{~cm}$ and the mean weight was $130.8 \pm 23 \mathrm{~g}$ for samples harvested in 2005. In 2003, snow crabs of smaller size were harvested. The $t$ test shows significant difference between length, width, and weight of the samples harvested in 2003 and 2005. Table 1 shows the descriptive statistics of length, width, and dry weight of total samples analyzed. The average size crab is viable for commercialization (the crab must have a width greater than $9.5 \mathrm{~cm}$ (only the males are sold)). Supplementary Figure 1 shows the mean proximate composition of snow crabs harvested in 2003 and 2005.

Table 2 gives the proximate composition of shells of snow crab. The analyses have been carried out in duplicate. The mean percentage moisture obtained was $72.0 \% \pm 5.8$. Results are expressed in dry weight; proteins were in higher content, followed by minerals and lipids.

Lipid content is a key factor in the diet for human consumption and aquatic species. High lipid levels (between $16 \%$ and $35 \%$, depending on species and growing conditions) serve to save most of the protein and achieve excellent growth. The fatty acid profile of Chionoecetes opilio shells was dominated by polyunsaturated fatty acids, especially $\omega 3$, docosahexanoic acid (DHA), and eicosapentaenoic acid (EPA) (VilasoaMartinez et al., 2009).

The amino acid content (Table 3 ) in snow crab shells is important. The shells presented the following essential amino acids: methionine, arginine, threonine, tryptophan (is deleted in the method used), histidine, isoleucine, lysine, leucine, valine, and phenylalanine. Of these, methionine and lysine are essential for aquatic species (Li, Mai, Trushenki, \& Wu, 2009; Mach et al., 2010; Smith, Tabrett, Barclay, \& Irvin, 2005). Besides the high protein content, it has an amino acid composition suitable for human consumption. 
Mineral content is also important because low concentrations in aquatic diets can have adverse effects on reproduction (Lee et al., 2010).

The content of vitamin E, $23.31 \mathrm{mg} / 100 \mathrm{~g} \mathrm{dw}$ (Vilasoa-Martinez et al., 2008), takes on significant importance due to its antioxidant. The higher value of carotenoids corresponds to astaxanthin (VilasoaMartinez et al., 2008), primary pigments in crustaceans shell color. The astaxanthin is used for humans as a food supplement. This pigment is very useful in aquaculture (Christiansen \& Torrisen, 1996) because the fish cannot synthesize carotenoids (present in invertebrates), and their addition to feeds is an additional economic value.

\section{Discussion}

According to the literature, the proximate composition of discarded shell from various crustaceans could be used in diets for human consumption and fish as an alternative animal protein (Gigliotti, Jaczynski, \& Tou, 2008; Mach et al., 2010; Özogul, 2000) or in other feeds (Gyeong Bong, 2007; Skonberg et al., 2001). The protein content of our snow crab sample $(34.2 \% \mathrm{dw})$ is higher than that reported by other authors (Manu-Tawiah \& Haard, 1987; Shahidi \& Synowiecki, 1991), but slightly lower than that found by other authors in other crustaceans, also used in the manufacture of feed, as shrimp shell wastes (Heu et. al. 2003; Oliveira Cavalheiro et. al. 2007; Shahidi \& Synowiecki, 1991; Smith et al., 2005 ) and than hard shell crab lump and claw (Benjakul \& Suttipan, 2009), while the ash content is similar. However, the lipid content of snow crab shells (17.1\% dw) was higher (Benjakul \& Suttipan, 2009; Heu et al., 2003; Manu-Tawiah \& Haard, 1987; Naczk, Williams, Brennan, Liyanapathirana, \& Shahidi, 2004; Oliveira Cavalheiro et al., 2007; Ramamohanrao, Kallapur, \& Narasubhai, 1983; Shahidi \& Synowiecki, 1991), and thus it can be used as a feed for aquatic species.

Snow crab shells have a high economic potential because their mean weight is similar to the mean weights of other whole crabs, such as blue crab, swim crab (Gökoolu \& Yerlikaya, 2003), or green crabs (Skonberg \& Perkins, 2002). Velu \& Munuswamy (2007) indicate the nutritional value of crustaceans as potential candidates for use in diets. Compared to our snow crab shells, the reported moisture and protein content in meat were higher, however, it is not the same for total lipids and ash content. In our snow crab shells, the lipid content and ash are higher than the crustacean meat, and it is similar to that found in snow crab by-products (Beaulieu et al., 2009) and for edible viscera (Chen, Zhang, \& Shersta, 2007) and hepatopancreas (Latyshev, Kasyanov, Kharlamenko, \& Svetashev, 2009). It is a test of the nutritional value of such by-products, with values equal to or greater than edible crustaceans, which are discarded.

In the other hand, the fatty acid profile of Chionoecetes opilio crab shell had predominantly polyunsaturated fatty acids, especially $\omega 3$. Fatty acids such as eicosapentanoic acid (EPA) and docosahexanoic acid (DHA) are considered essential for marine fish and must be provided in the diet. The relationship $\omega 6 / \omega 3$ is 0.08 according to Latyshev et al. (2009) and 0.1 according to Beaulieu et al. (2009), and represents a good index of nutritional value, for snow crab oil by-products, while in other crabs and shrimp, $\omega 3$ is in a lower percentage and the ratio is higher (Chen et al., 2007; Heu et al., 2003; Latyshev et al., 2009).

The $\omega 3$ polyunsaturated fatty acids have been reported to have various beneficial health effects that include reducing the risk of cardiovascular diseases (Ferraro et al., 2010). The snow crab shells might be considered as an innovative source of $\omega 3$ long chain polyunsaturated fatty acids for human and aquaculture feeding purposes (Beaulieu et al., 2009; Bransden, Battaglene, Morehead, Dunstan, \& Nichols, 2005; Ferraro et al., 2010).

In what regards to amino acids, Beaulieu et al. (2009) showed that protein-enriched fractions demonstrate a well-balanced amino acid composition, especially including essential amino acids with potential application benefits for promoting human health.

In the aquaculture diet, the essential amino acids are also required for maintenance, growth, and reproduction. Jaswal (1990) reported substantially higher results for the studied amino acids in the same type of crab and Heu et al. (2003) in by-products of shrimp. In Chinese mitten crab, similar content and profile was found (Chen et al., 2007). Moreover, Li et al. (2009) showed that some amino acids are important regulators of key metabolic pathways that are necessary for maintenance, growth, feed intake, nutrient utilization, immunity, reproduction, behavior, larval metamorphosis, as well as resistance to environmental stressors and pathogenic organisms in various fishes.

As expected, minerals, especially calcium, were present in higher amounts in shells, and may serve as nutritional components for applications in food sectors (Beaulieu et al., 2009; Ferraro et al., 2010; Shahidi \& Synowiecki, 1991). Calcium content is higher in the exoskeleton of crab and lobster, followed by phosphorus and magnesium; and it is similar to the one found in their by-products of crabs and shrimps (Boßelmann, Romano, Fabritius, Raabe, \& Epple, 2007; Heu et al., 2003; Velu \& Munuswamy, 2007). Studies by Toppe et al. (2006) and Lee et al. (2010) indicate that high ash raw materials, such as crab by-products, may successfully be utilized as feed ingredient in cod feeds and rainbow trout, respectively.

An important quality factor, which affects consumer acceptance and market value, of many species of fish and shellfish is the pink or red meat or exoskeleton after being boiled. In nature, this coloration is derived from the ingestion of carotenoid pigments found in invertebrates, because fish may not synthesize, and it is mainly due to astaxanthin. Shell wastes from snow crab may find use as 
a dietary source of colorant for cultured salmonids (Christiansen \& Torrissen, 1996; Ferraro et al., 2010; Manu-Tawiah \& Haard, 1987). Research in this field has showed that all fish feed carotenoid supplement diets displayed a pink-colored skin and astaxanthin diesters were the major carotenoids in the skin of pink fish (Lawrence, Tsushima, George, \& Lawrence, 2002; Moretti et al., 2006; Shahidi \& Synowiecki, 1991; Tejera et al., 2007), but their addition to feed as a synthetic product is expensive. Besides the role of carotenoids in the pigmentation of the muscle, they also act as precursors of vitamin $\mathrm{A}$ and as an antioxidant protecting body fat from peroxidation. The presence of vitamin $\mathrm{E}$ and carotenoid pigments, mainly astaxanthin, in shell crabs makes them a potential source for the elaboration of organic feed in aquaculture.

The primary use of carotenoid pigments for human consumption is as a food supplement. Research shows that due to astaxanthin potent antioxidant activity, it may be beneficial in cardiovascular, immune, inflammatory, and neurodegenerative diseases (Fasset \& Coombes, 2009) Few researches have suggested it potential as an anti-cancer agent (Palozza et al., 2009). Research supports the assumption that it protects body tissues from oxidative damage.

Results presented in this study are in agreement with other studies and indicate that snow crab byproducts may serve as excellent nutritional components for future applications in the health and food sectors. Many potential application benefits for promoting human health are possible due to the bioactive compounds found in snow crab by-products.

\section{Conclusions}

This study shows that the great volume of discarded snow crab shells, with great economic and nutritive potential as components of formulations of high valueadded compounds, can be employed as excellent nutritional components in future in the health and food sectors. Snow crab shells have high protein content, essential amino acids, and fat, mostly polyunsaturated fatty acid $\omega 3$, carotenoids, and minerals (calcium, phosphorus, and magnesium). Therefore, these by-products meet many of the characteristics and requirements of human and aquaculture food and may be of interest as health-promoting agents, dietary protein, and as lipid or mineral supplements.

\section{Supplementary material}

The supplementary material for this article is available at http://dx.doi.org/10.1080/19476337.2011.596285

\section{Acknowledgements}

This work was supported by the Consellería de Educación e Ordenación Universitaria da Xunta de Galicia (Project PGIDIT03BTF00701CT). Technical assistance of Patricia Ferraces Casais is highly appreciated.

\section{References}

AOAC. (1990). Ash in seafood (938-08) Official Methods of Analysis (15th ed., Vol. 2). Washington, DC: Association of Official Analytical Chemists, pp. 868.

Beaulieu, L., Thibodeau, J., Bryl, P., \& Carbonneau, M.E. (2009). Characterization of enzymatic hydrolyzed snow crab (Chionoecetes opilio) by-product fractions: A source of high-valued biomolecules. Bioresource Technology, 100, 3332-3342.

Benjakul, S., \& Suttipan, N. (2009). Comparative study on chemical composition, thermal properties and microstructure between the muscle of hard shell and soft shell mude crabs. Food Chemistry, 112, 627-633.

Boßelmann, F., Romano, P., Fabritius, H., Raabe, D., \& Epple, M. (2007). The composition of the exoskeleton of two crustacea: The American lobster Homarus americanus and the edible crab Cancer pagurus. Thermochimica Acta, 463, 65-68.

Bransden, M.P., Battaglene, S.C., Morehead, D.T., Dunstan, G.A., \& Nichols, P.D. (2005). Effect of dietary 22:6n-3 on growth, survival and tissue fatty acid profile of striped trumpeter (Latris lineata) larvae fed enriched Artemia. Aquaculture, 243, 331-344.

Chen, D., Zhang, M., \& Shersta, S. (2007). Compositional characteristics and nutritional quality of Chinese mitten crab (Eriocheir sinensis). Food Chemistry, 103, 1343-1349.

Christiansen, R., \& Torrissen, O.J. (1996). Growth and survival of Atlantic salmon, Salmo salar L. fed different diets and levels of axtasanthin. Juveniles. Aquaculture Nutrition, 2(1), 55-62.

Fasset, R.G., \& Coombes, J. (2009). Astaxanthin, oxidative stress, inflammation and cardiovascular disease. Future Cardiology, 4, 333-342.

Ferraro, V., Cruz, I.B., Ferreira, J.R., Malcata, X., Pintado, M.E., \& Castro, P. (2010). Valorisation of natural extracts from marine source focused on marine by-products: A review. Food Research International, 43, 22212233.

Gigliotti, J.C., Jaczyns, J., \& Tou, J.C. (2008). Determination of the nutritional value, protein quality and safety of krill protein concentrate isolated using an isoelectric solubilization/precipitation technique. Food Chemistry, $111,209-214$.

Gökoolu, N., \& Yerlikaya, P. (2003). Determination of proximate composition and mineral contents of blue crab (Callinectes sapidus) and swim crab (Portunus pelagicus) caught off the Gulf of Antalya. Food Chemistry, 80, 495-498.

Gyeong Bong, B. (2007). Method for preparing liquid powder using snow crab. Patent application KR 2006-9682 20060201. Korea: Repub. Korean Kongkae Taeho Kongbo.

Heu, M., Kim, J., \& Shahidi, F. (2003). Components and nutritional quality of shrimp processing by-products. Food Chemistry, 82, 235-242.

Jaswal, A.S. (1990). Amino acid hydrolysate from crab processing waste. Journal of Food Science, 55, 379-380.

Latyshev, N.A., Kasyanov, S.P., Kharlamenko, V.I., \& Svetashev, V.I. (2009). Lipids and of fatty acids of edible crabs of the north-western Pacific. Food Chemistry, 116, 657-661.

Lawrence, J.M., Tsushima, S.B., George, A.L., \& Lawrence, L.R. (2002). Carotenoids and sea urchins. Panorama Acuicola Magazin, 7, 24-25.

Lee, K.-J, Powell, M.S., Barrows, F.T., Smiley, S., Bechtel, P., \& Hardy, R.W. (2010). Evaluation of supplemental fish bone meal made from Alaska seafood processing byproducts and dicalcium phosphate in plant protein based diets for rainbow trout (Oncorhynchus mykiss). Aquaculture, 302, 248-255. 
Li, P., Mai, K., Trushenki, J., \& Wu, G. (2009). New developments in fish amino acid nutrition: Towards functional and environmentally oriented aquafeeds. Amino Acids, 37, 43-53.

Mach, D.T.N., Nguyen, M.D., \& Nortvedt, R. (2010). Effects on digestibility and growth of juvenile cobia (Rachycentron canadum) fed fish or crab silage protein. Aquaculture Nutrition, 16, 395-312.

Manu-Tawiah, W., \& Haard, N.F. (1987). Recovery of carotenoprotein from the exoskeleton of snow crab Chionoecetes opilio. CIFST (Canadian Institute of Food Science and Technology Journal), 20, 31-33.

Moretti, V.M., Mentasti, T., Bellagamba, F., Luzzana, U., Caprino, F., Turchini, G.M., Giani, I., \& Valfrè, F. (2006). Determination of astaxanthin stereoisomers and colour attributes in flesh of rainbow trout (Oncorhynchus mykiss) as a tool to distinguish the dietary pigmentation source. Food Additives and Contaminants, 23, 1056-1063.

Murphy, M.G., Skonberg, D.L., Camire, M.E., Dougherty, M.P., Bayer, R.C., \& Briggs, J.L. (2003). Chemical composition and physical properties of extruded snacks containing crab-processing by-product. Journal of the Science of Food and Agriculture, 83, 1163-1167.

Naczk, M., Williams, J., Brennan, K., Liyanapathirana, C., \& Shahidi, F. (2004). Compositional characteristics of green crab (Carcinus maenas). Food Chemistry, 88, 429-434.

Obatolu, V.A., Skonberg, D.I., Camire, M.E., \& Dougherty, M.P. (2005). Effect of moisture content and screw speed on the physical chemical properties of an extruded crabbased snack. Food Science and Technology International, $11,121-127$.

Oliveira Cavalheiro, J.M, Oliveira de Souza, E, \& Bora, P.S. (2007). Utilization of shrimp industry waste in the formulation of tilapia (Oreochromis niloticus Linnaeus) feed. Bioresource Technology, 98, 602-606.

Özogul, Y. (2000). The possibility of using crustacean waste products (CWP) on rainbow trout (Oncorhynchus mykiss) feeding. Turk. Journal of Biology, 24, 845-854.

Palozza, P., Torelli, C., Boninsegna, A., Simone, R., Catalano, A., Mele, M.C., \& Picci, N. (2009). Growthinhibitory effects of the astaxanthin-rich alga Haematococcus pluvialis in human colon cancer cells. Cancer Letter, 283(1), 108-117.

Ramamohanrao, Y., Kallapur, V.L., \& Narasubhai, A.V. (1983). Lipid composition of the shell of the field crab Paratelphusa hydrodomus. Journal of Animal. Morphology \& Physiology, 30, 188-195.

Rosa, R., \& Nunes, M.L. (2003). Nutritional quality of red shrimp, Aristeus antennatus (Risso), pink shrimp, Parapenaeus longirostris (Lucas), and Norway obster, Nephrops norvegicus (Linnaeus). Journal of the Science of Food and Agriculture, 84, 89-94.
Shahidi, F. (2006). Maximizing the value of marine by-products. Cambridge, England: CRC Woodhead Press.

Shahidi, F., \& Synowiecki, J. (1991). Isolation and characterization of nutrients and value-added products from snow crab (Chionoecetes opilio) and shrimp (Pandalus borealis) processing discards. Journal of Agriculture and Food Chemistry, 39, 1527-1532.

Skonberg, D.I., Donahue, D.W., Bayer, R.C., Floreto, E., \& Riley, J.G. (2001). Quality evaluation of American lobster fed diets containing processing waste. Journal of Aquatic Food Product Technology, 10, 17-29.

Skonberg, D.I., \& Perkins, B.L. (2002). Nutrient composition of green crab (Carcinus maenus) leg meat and claw meat. Food Chemistry, 77, 401-404.

Smith, D.M., Tabrett, S.J., Barclay, M.C., \& Irvin, S.J. (2005). The efficacy of ingredients included in shrimp feeds to stimulate intake. Aquaculture Nutrition, 11, 263-272.

Tejera, N., Cejas, J.R., Rodriguez, C., Bjerkeng, B., Jerez, S., Bolaños, A., \& Lorenzo, A. (2007). Pigmentation, carotenoids, lipid peroxides and lipid composition of skin of red porgy (Pagrus pagrus) fed diets supplemented with different astaxanthin sources. Aquaculture, 270, 218230.

Tibbetts, S.M., Olsen, R.E., \& Lall, S.P. (2011). Effects of partial or total replacement of fish meal with freeze-dried krill (Euphasia superba) on growth and nutrient utilization of juvenile atlantic cod (Gadus morhua and Atlantic halibut 8 Hippoglossus hippoglossus) fed the same practical diets. Aquaculture Nutrition, 17, 287-303.

Toppe, J., Aksnes, A., Hope, B., \& Albrektsen, S. (2006). Inclusion of fish bone and crab by-products in diets for Atlantic cod, Gadus morhua. Aquaculture, 53, 636-645.

Velu, C.S., \& Munuswamy, N. (2007). Composition and nutritional efficacy of adult fairy shrimp Streptocephalus dichotomus as live feed. Food Chemistry, 100, 1435-1442.

Vilasoa-Martinez, M., Calaza-Ramos, C., Lopez-Hernandez, J., Lage-Yusty, M.A., Paseiro Losada, P, \& Rodríguez Bernaldo de Quirós, A. (2008). Determination of vitamin $\mathrm{E}$ and carotenoid pigments by high performance liquid chromatography in shell of Chionoecetes opilio. Analytica Chimica Acta, 617, 225-229.

Vilasoa-Martinez, M., Lopez-Hernandez, J., \& Lage-Yusty, M.A. (2007). Protein and amino acid contents in the crab, Chionoecetes opilio. Food Chemistry, 103, 1330-1336.

Vilasoa-Martinez, M., Rodríguez Bernaldo de Quirós, A, López Hernández, J, \& Lage Yusty, M.A. (2009). Fatty acid profile and total lipid content of Chionoecetes opilio shells. The Open Food Science Journal, 3, 93-97. 